\title{
Influence of Temperature and Carbonation on Chloride Induced Corrosion of Carbon Steel in Concrete Pore Solutions
}

\author{
Jie Zha, Linhua Jiang ${ }^{*}$, Peng Xu, Ming Jin, Peng Jiang \\ College of Mechanics and Materials, Hohai University, Nanjing 210098, PR China. \\ *E-mail: lhjiang@hhu.edu.cn
}

Received: 5 October 2021 / Accepted: 8 November 2021 / Published: 6 December 2021

\begin{abstract}
The effects of the temperature, carbonation, and different types of synthetic solutions on chloride corrosion of steel reinforcement were investigated in this paper. A relatively wide range of temperatures (from $5^{\circ} \mathrm{C}$ to $60^{\circ} \mathrm{C}$ ) and three synthetic solutions $\left(\mathrm{Ca}(\mathrm{OH})_{2}+\mathrm{KOH}+\mathrm{NaOH}\right.$ solution, the cement and cement-slag extracts) were applied. In addition, a high concentration of bicarbonate ions $(0.2 \mathrm{~mol} / \mathrm{L})$ was used to simulate the effect of carbonation. The open-circuit potential and corrosion current density were obtained from the linear polarization resistance and EIS results to evaluate the corrosion resistance of samples. Higher temperatures increase the corrosion of steel above $20^{\circ} \mathrm{C}$. This is accounted for by the acceleration of both the corrosion reaction and dissolution of passive films. The lower temperature $\left(5^{\circ} \mathrm{C}\right)$ similarly promotes corrosion due to the increased dissolved oxygen in the solutions. The existence of $\mathrm{HCO}_{3}{ }^{-}$inhibits the corrosion process in traditional synthetic solutions under $40^{\circ} \mathrm{C}$ but promotes corrosion at $60^{\circ} \mathrm{C}$, which can be attributed to the buffering influence of ions and decomposition. The traditional synthetic solutions and cement extracts are more appropriate for simulation of the effect of temperature and carbonation.
\end{abstract}

Keywords: temperature, carbonation, chloride ions, reinforcement corrosion, cement, slag

\section{FULL TEXT}

(C) 2022 The Authors. Published by ESG (www.electrochemsci.org). This article is an open access article distributed under the terms and conditions of the Creative Commons Attribution license (http://creativecommons.org/licenses/by/4.0/). 